58, 244(1962)

7) M. Morton, A. Rembaum, E. E. Bostick : J. Polymer Sci., 22, 189(1956)

8) D. H. Richards, M. Szwarc: Trans. Faraday Soc., 55, 1644(1959)

9) 三田 達, 神戸博太郎, 大橋 隆：高分子学会年 次大会 (1963 年 5 月, 東京)

10) 滝田 博, 野呂 健：21，445(1964)

11) R. A. Friedel, M. Orchin: “Ultraviolet Spectra of Aromatic Compounds, John Wiley and Sons. Inc. (1951)
12) 滝田 博, 野呂 健：高化, 20, 705(1963)

13) 滝田 博, 野呂 健: 高化, 21, 23(1964)

14) N. D. Scott, J. F. Walker, V. L. Hansley : J. Am. Chem. Soc., 58, 2442(1936)

15）野呂 健, 川面博司, 吉岡節夫：ゴムおよび高分 子の研究発表会 (1963 年 11 月, 名古屋)

16) K. S. Das, M. Feld, M. Szwarc: J. Am. Chem. Soc., 82, 1506(1960)

17）広田鋼蔵, 桑田敬治, 戸川晴雄, 石田慎一：日化, $79,602(1958)$

\title{
Anionic Polymerization of Aldehydes
}

\section{Polymerization of Acetaldehyde with Alkali Metal- Aromatic Hydrocarbon Complexes}

\author{
By Hiroshi Takida* and Ken Noro*
}

\begin{abstract}
Polymerization of acetaldehyde with alkali metal-aromatic hydrocarbon complexes as catalyst was studied. Lithium, sodium and potassium were used as alkali metals and naphthalene and anthracene were used as aromatic hydrocarbons. Low polymer yield and low crystallinity of polymer were obtained when polymerization was carried out at $-78^{\circ} \mathrm{C}$ with any of these complex catalyst. However, both yield and cyrstallinity of polymer increased when polymerization temperature was reduced to $-100^{\circ} \mathrm{C}$. Polymerization depended upon the sort of alkali metal, but was independent of the sort of aromatic hydrocarbon. Generally, high polymer yield was obtained when polar solvent was used and crystallinity of polymer was the lowest when tetrahydrofuran was used as solvent. High crystalline polymer was obtained in relatively high yield when ethylether or toluene was used as solvent.

Refering with the solubility in acetone and chloroform with infrared spectrum of the polymer, it was observed that the ratio of optical density at $8.4 \mu$ and $9.6 \mu$ could semi-quantitatively represent the crystallinity of the polymer.
\end{abstract}

第 3 報 リビングポリマーによるアセトアルデヒドのブロック共重合 (1964 年 3 月 2 日受理)

$$
\text { 滝田 博**. 野呂 健** }
$$

\footnotetext{
要旨 アルカリ金属一芳香族炭化水素錯合体，扰よび $n$-プチルリチウムのよらなアルカリ金属を含む 触媒を用いて，スチレン， $\alpha$-メチルスチレン, 2-メチルー5-ピニルピリジン, メタクリル酸メチル, イソプレ ン，およびブタジェンのリビングポリマーをつくり，これにアセトアルデヒドを加えて低温で重合を行ない，

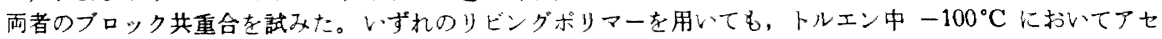
トアルデヒドの重合が可能であり, 結晶性ポリアセトアルデヒドを主成分とするポリマーが得られ, 赤外吸収 スペクトルによる知見から，両者のブロック共重合体がつくられているもの上考えられる。これらのブロック 共重合体はアアセトアルデヒドのホモポリマーに比較して熱安定性が良好である。
}

\section{1. 緒言}

前報1)(2)において, アルカリ金属を含む解媒を用いた
場台においても適当な条件の下では，これらがアセトア ルデヒドの有効な重合触媒となり, 結晶性のすぐれたボ リマーの得られることが明らかにされた。

* Central Research Laboratory, The Nippon Synthetic Chemical Industry Co., Ltd. (156 Kamikema, Amagasaki, Hyogo)

** 日本合成化学工業株式会社中央研究所 (兵庫県尼崎市上食満 156) 
これらの触媒は, 従来, リビングポリマー合成の触媒 としてよく知られたものであり,リビングポリマーは, これに適当なモノマーを加えることによって容易にブロ ック共重合体をつくることが可能であって, 種々の研究 が行なわれているす。 。しかながら，任意の組合せのリ ビングポリマーとモノマーの間で, 必ずしもブロック共 重合が起こるものではなく、たとえば, リビングポリス チレンは,メタクリル酸メチル, アクリロニトリルの重 合を開始させるが,ポリメタクリル酸メチルのアニオン, あるいは,ポリアクリロニトリルのアニオンではスチレ ンの重合は起こらない(4),

アセトアルデヒドのブロック共重合に関しては, 二段 重合によるプロピレンオキサイドとのプロック共重合が 試みられ、ポリマーの熱安定性の向上に著しい効果が認 められている6)。リビングポリマーを用いれば、ブロッ ク共重合ははるかに容易であろうと考えられ, 種々のも ノマーとのブロック形成, さらには, 両者の組成比を広 範囲に変えることも，理論的には可能であろう。

本報告では，前報1,2) で得られた知見をもとにして， 種々のリビングポリマーによるアセトアルデヒドのブロ ック共重合を試み、ポリマーの熱安定性の向上に主眼を おいて検討を行なった。

\section{2. 実臨}

\section{1 試 藩}

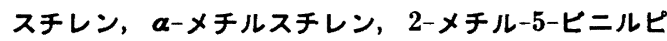
リジン：市販品を减圧蒸留後, 金属ナトリウムであら かじめ脱水し, 高真空下 $\left(10^{-4} \mathrm{mmHg}\right)$ ナトリウム蒸着 膜をつけたU 字管にモノマー蒸気を通して十分に脱水, 精製した。
メタクリル酸メチル (MMA)：市販品を減圧蒸留後， モレキュラーシーブであらかじめ脱水し, 上と同様の方 法により脱水, 精製した。

フタジェン, インプレン：市販品を高真空下, 金属 ナトリウムを蒸着させた U 字管を通して脱水, 精製 した。

アセトアルデヒト，溶媒： 前報1同様の方法により精 製した。

\section{2 触媒の調製}

前報1),2記載に準ずる。

\section{3 重 合}

前報”で述べた重合装置を用いた。触媒, および溶媒 を重合容器に仕込んだ後, これにモノマーを加え, あら かじめ所定温度でリビングポリマーをつくっておき,こ れを所定温度に泠却してアセトアルデヒドを蒸留仕込 み，重合を行なわせる。リビングポリマーの生成は，重 合采の色の変化で容易に判定される。他の操作は前報 どおりである。

\section{4 ポリマーの分別および種々の測定}

前報”同様である。分別はアセトンおよびクロロホル ムを溶媒とし $30^{\circ} \mathrm{C}$ において行なった。

\section{3. 結 果}

\section{1 重 合}

リビングポリマーの作製条件を Table 1 に, また, ア セトアルデヒドの重合結果を Table 2 に示す。

リビングポリマーの溶液に，アセトアルデヒドを蒸留 仕込みしてゆくと，重合系は直ちに退色して無色となり， アルデヒドの重合が起こってかきまぜは逐次因難とな る。アセトアルデヒドの重合を低温で行なう関倸上,特

Table 1. Preparation of various "living" polymers.

\begin{tabular}{l|l|l|c|c|c}
\multicolumn{1}{c|}{ Monomer } & \multicolumn{1}{|c|}{ Catalyst } & Solvent & $\begin{array}{c}\text { Polymerization } \\
\text { temp. }\left({ }^{\circ} \mathrm{C}\right)\end{array}$ & $\begin{array}{c}\text { Polymerization } \\
\text { time (hr) }\end{array}$ & $\begin{array}{c}\text { Color of } \\
\text { product }\end{array}$ \\
\hline \multirow{2}{*}{ Styrene } & Li, Na, K-naphthalene & Toluene & -78 & 20 & Red \\
MVP & $n$-Butyl lithium & Toluene & 40 & 2 & \\
& Li, Na, K-naphthalene & Toluene & Room temp. & 20 & Red \\
$\alpha$-Methyl-styrene & $n$-Butyl lithium & Toluene & 40 & 2 & Orange \\
MMA & Na-naphthalene & Toluene & -78 & 20 & Red \\
& $n$-Butyl lithium & Toluene & -78 & 2 & \\
Isoprene & Na-naphthalene & Toluene & -78 & 20 & Yellow \\
& $n$-Butyl lithium & Toluene & 40 & 2 & Colorless \\
Butadiene & Na-naphthalene & Toluene & 0 & 20 & Yellow \\
& $n$-Butyl lithium & Toluene & 40 & 2 & \\
& Na-naphthalene & Toluene & -78 & 20 & Yellow \\
& $n$-Butyl lithium & Toluene & 40 & 2 & \\
\hline
\end{tabular}


Table 2. Block copolymerization of acetaldehyde with various comonomers.

(Acetaldehyde : $10 \mathrm{ml}$, Polymerization of acetaldehyde: $-100^{\circ} \mathrm{C}, 3 \mathrm{hr}$ )

\begin{tabular}{|c|c|c|c|c|c|c|c|c|c|}
\hline \multirow{3}{*}{$\begin{array}{l}\begin{array}{l}\text { Exp. } \\
\text { No. }\end{array} \\
1056\end{array}$} & \multirow{2}{*}{\multicolumn{2}{|c|}{$\begin{array}{l}\text { Catalyst } \\
\left(10^{-4} \mathrm{~mol}\right)\end{array}$}} & \multirow{2}{*}{\multicolumn{2}{|c|}{$\begin{array}{l}\text { Comonomer } \\
(\mathrm{m} l)\end{array}$}} & \multirow{2}{*}{\multicolumn{2}{|c|}{$\begin{array}{l}\text { Solvent } \\
\qquad(\mathrm{m} l)\end{array}$}} & \multicolumn{2}{|c|}{ Polymer yield (\%) } & \multirow{2}{*}{$D_{8.4} / D_{9.6}$} \\
\hline & & & & & & & Insoluble $e^{a)}$ & Soluble $e^{\text {b) }}$ & \\
\hline & $\mathrm{Na}$-Naphthalene & 1.4 & Styrene & 1.0 & Toluene & 20 & 13.8 & 6.0 & 1.27 \\
\hline 1064 & $\mathrm{Na}$-Naphthalene & 5.7 & Styrene & 1.0 & Toluene & 20 & 44.8 & 8.6 & 1.37 \\
\hline 1065 & Na-Naphthalene & 5.7 & Styrene & 0.5 & Toluene & 20 & 37.6 & 4.5 & 1.19 \\
\hline 1057 & Na-Naphthalene & 1.4 & MVP & 0.5 & Toluene & 20 & 10.2 & 6.1 & 1.28 \\
\hline 1058 & $\mathrm{Na}$-Naphthalene & 5.7 & MVP & 0.5 & Toluene & 20 & 38.5 & 6.5 & 1.19 \\
\hline 1059 & $\mathrm{Na}$-Naphthalene & 5.7 & MVP & 1.0 & Toluene & 20 & 50.6 & 6.9 & 1.09 \\
\hline 1060 & $\mathrm{Na}$-Naphthalene & 5.7 & $\alpha$-Methyl-styrene & 0.5 & Toluene & 20 & 20.3 & 3.4 & 1.45 \\
\hline 1062 & $\mathrm{Na}$-Naphthalene & 5.7 & MMA & 1.0 & Toluene & 20 & 10.3 & 12.5 & 1.38 \\
\hline 1063 & $\mathrm{Na}$-Naphthalene & 5.7 & MMA & 0.5 & Toluene & 20 & 50.0 & 7.7 & 0.89 \\
\hline 1067 & $\mathrm{Na}$-Naphthalene & 5.7 & Isoprene & 0.5 & Toluene & 20 & 31.0 & 2.8 & 1.29 \\
\hline 1068 & $\mathrm{Na}-\mathrm{Naphthalene}$ & 5.7 & Butadiene & 1.0 & Toluene & 20 & 50.2 & 16.5 & 1.05 \\
\hline 1069 & $\mathrm{Na}$-Naphthalene & 5.7 & Butadiene & 0.5 & Toluene & 20 & 47.8 & 6.1 & 0.96 \\
\hline 1070 & Li-Naphthalene & 5.9 & Styrene & 1.0 & Toluene & 20 & 48.0 & 8.0 & 1.10 \\
\hline 1071 & Li-Naphthalene & 5.9 & MVP & 1.0 & Toluene & 20 & 41.4 & 9.4 & 1.11 \\
\hline 1073 & K- Naphthalene & 4.4 & Styrene & 1.0 & Toluene & 20 & 5.7 & 11.0 & 1.50 \\
\hline 1072 & K- Naphthalene & 4.4 & MVP & 1.0 & Toluene & 20 & 3.1 & 8.0 & 1.54 \\
\hline $\mathrm{L}-151$ & $\mathrm{BuLi}$ & 5.3 & Styrene & 1.0 & Toluene & 20 & 29.7 & 5.0 & 1.35 \\
\hline $\mathrm{L}-152$ & $\mathrm{BuLi}$ & 10.6 & MMA & 2.0 & Toluene & 20 & 24.5 & 23.0 & 1.43 \\
\hline$L-154$ & BuLi & 10.6 & MMA & 0.5 & Toluene & 20 & 46.5 & 0.7 & 1.39 \\
\hline $\mathrm{L}-153$ & $\mathrm{BuLi}$ & 10.6 & Butadiene & 1.0 & Toluene & 20 & 30.2 & 1.7 & 1.59 \\
\hline L-155 & BuLi & 10.6 & Isoprene & 1.0 & Toluene & 20 & 37.2 & 2.5 & - \\
\hline $\mathrm{L}-157$ & $\mathrm{BuLi}$ & 10.6 & MVP & 1.0 & Toluene & 20 & 45.1 & 15.0 & 0.99 \\
\hline L-159 & $\mathrm{BuLi}$ & 10.6 & $\alpha$-Methyl-styrene & 1.0 & Toluene & 20 & 24.6 & 0.8 & 1.07 \\
\hline
\end{tabular}

a), b): Insoluble or soluble part after polymerization mixture was washed with cold acetone, respectively.

にかきませの状態は, リビングポリマー溶液の粘度で大 きく左右され, 全収率, したがって, 触媒効率は系の粘 度に大きく依存する。主として，かきまぜの不十分なこ とから,ポリマーのブロック勃率はあまり良好といえず, 赤外吸收スペクトルによれば, 重合混合物を冷アセトン で洗浄後の口液残渣は、リビングポリマーに由来するポ リマーの割合が多く，この部分は，たとえ，アセトアル デヒドがブロックしているとしても，その量は少ないと

\section{考えられる。}

得られたポリマーの X 線回折曲線,および赤外吸収 スペクトルの一例を示せば, Fig. 1 および Fig. 2 のご とくであり，結晶性ポリアセトアルデヒドを主成分とす るポリマーであることがうかがわれる。

\section{2 ポリマーの組成}

リビングポリマーを用いて得られるアセトアルデヒド ポリマーの組成を知ることは,ブロック共重合の効率, ポ リマーの安定性向上への効果などの点から重要である。
このポリマーは, いわゆるブロック共重合体であるか ら，ランダム共重合体と異なり，赤外吸収スペクトルは 成分ポリマーの混合物に近い吸収を示すと考えられる。

したがって、いろいろの既知割合で混合した両種ポリ マーの混合物について，あらかじめ赤外吸収スペクトル を測定し, 両者の特性吸収から検量線を求めておけば, 比較的簡単に，その組成を知りらるものと考えられる。 そこで,ポリマーの組成決定は, 赤外吸収スペクトルに よることにした。

既述のごとく ${ }^{1), 2)}$ ，この種の触媒によるポリアセトア ルデヒドは，結晶性であるため，これを完全に溶解する 溶媒がない。ポリマーの混合を固体状で行ならことは, 試料均一性の点から問題の多いことは明らかである。一 方, 非晶性のポリマーは, 広簛囲の溶媒に可溶である。 この可溶性ポリアセトアルデヒドは, ブロック成分の, いま一つのポリマーとともに, 共通の溶媒(たとえば, ク ロロホルム)に溶解混合して均一な赤外吸収スペクトル 


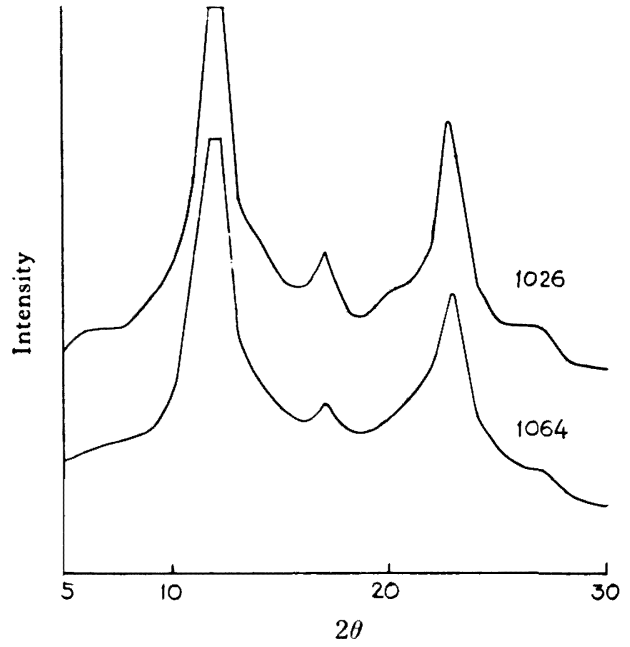

Fig. 1. X-ray diffraction pattern of polyacetaldehyde.
ポリブタジェン

$3.2 \mu\left(3095 \mathrm{~cm}^{-1}\right)$

イソプレン，およびブタジェンの ポリマーは, $6.1 \mu$ $\left(1650 \mathrm{~cm}^{-1}\right)$ 付近に, 强い吸収が存在するが, $\mathrm{KBr}$ 錠剤 法で測定を行なうときには， $\mathrm{KBr}$ 中に含まれる水の吸 収と重なるため，定量に用いることができない。そこで これらのブロック共重合体の組成決定は困難であり, 精 度が低い。

組成決定の結果は, 次節 3.3 のポリマーの分別結果 とともに Table 3 に示す。

\section{3 ポリマーの分別}

3.1 で得られたポリマーを, アセトン, 扩よびクロ口 ホルムで分別した。結果を Table 3 に示す。このポリ マーでは, ニモ/マー成分の共存により, 吸収の重なり の起こることがあるため， $D_{8.4} / D_{9.6}$ の值は，やや，正確 を久く場合があるが, Table 3 の結果より, 結晶性, お よび組成の両面で分別が同時に行なわれていることがわ かる。すなわち, 溶媒可溶部は, 不溶部に比してコモ, マー成分に富み，また， $D_{8.4} / D_{9.6}$ の值が小さい。

クロロホルム不溶部中に, コモノマー成分の存在する

用皮膜をつくるのに好都合である。 この際, ポリアセトアルデヒドの基 淮吸収としては，ポリマーの結晶性 に無関係なものを選ばねばならな い。ポリアセトアルデヒドの赤外吸 収スペクトルにみられる強い吸収の 中, 二つを選んで，その吸光度比を 求めると, $1347 \mathrm{~cm}^{-1}(7.5 \mu)$ 付近の 吸収と, $1443 \mathrm{~cm}^{-1}(6.7 \mu)$ の吸収の 吸光度比は, ポリマーの結晶性 $\left(D_{8.4} / D_{9.6}\right)$ に無関倸にほほとん゙一 定であった。

$7.5 \mu$ の吸収は, 他のポリマーの 吸収と重なることもなく、ブロック 共重合体の組成の決定には好適と思 われるのでこれを用いることにし た。なお，検量線作製用の非晶性ポ リアセトアルデヒドは, 硫酸マグネ シウムー硫酸錯合体を触媒として重 合したものである ${ }^{12)} 。$

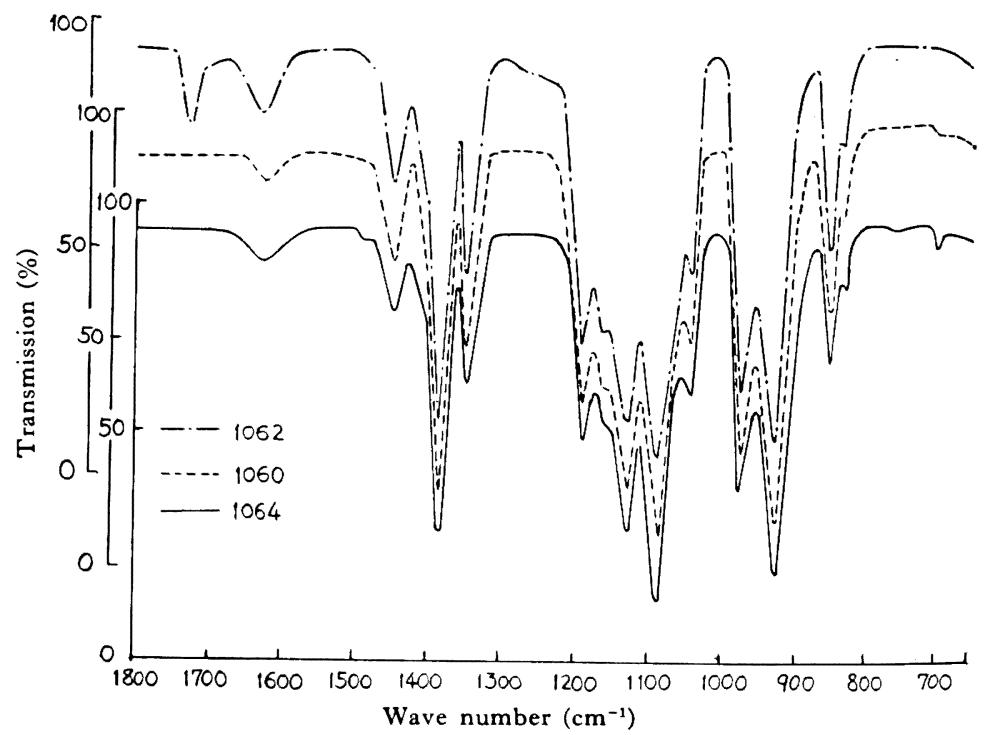

また, 各ポリマーについては, それらの特性吸収の中, ポリアセトアルデヒドの吸収と重ならないものを選ん だ。組成決定に用いた各吸収は次のようである。
ポリスチレン
$14.4 \mu\left(696 \mathrm{~cm}^{-1}\right)$
ポリ $\alpha$ メメルスチレン
$14.4 \mu\left(696 \mathrm{~cm}^{-1}\right)$

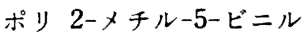
ピリジン $13.6 \mu\left(737 \mathrm{~cm}^{-1}\right)$
ポリメタクリル酸メチル
$5.8 \mu\left(1735 \mathrm{~cm}^{-1}\right)$
ポリインプレン
$3.2 \mu\left(3095 \mathrm{~cm}^{-1}\right)$

ことは，明らかにブロック共重合の一つの証拠と考える ことができる。ただ，この実験では，ホモポリマー量を 確実に定めることができなかったため, 正確なブロック 効率の算出はできなかった。

\section{4 ポリマーの安定性}

種々のリビングポリマーを用いて得られたアセトアル デヒドブロック共重合体の, $100^{\circ} \mathrm{C}$, 空気中における安定 性を検对した。結果を Fig. 3 および Fig. 4に示す。

これらの図には，比較のため，それぞれ、Naーナフタ 
レン, および $n$-ブチルリチウムを触媒として 得られた アセトアルデヒドホモポリマーの分解曲線も併示した。

Naーナフタレン, $n$ ーブチルリチウムのいずれを触媒と してリビングポリマーをつくった場合でも，得られたブ ロック共重合体の安定性は, ホモポリマーより良好であ る。

これらのポリマー 1 部を, ピリジン 40 部に浸漬し, これにピリジン一無水酢酸の等量混合物 20 部を加え, 窒 素気流中, $50^{\circ} \mathrm{C} て ゙ 2$ 時間反応させた後, 氷水洗浄, つ いでェチルェーテル洗浄を行ない, 室温で减圧乾燥する。

このようにしてアセチル化したポリマーの安定性を示 すと, Fig. 5 のようであり, 特に, 初期における熱分解 の著しい低下が認められる。

これと関連して, 別のアセチル化法によるアセトアル デヒドホモポリマーの安定性をみると, Fig. 6 のような 結果が得られる。図中, A-1 および A-2 は, Table 4 のような条件で重合後, 直ちに真空下で重合采に過剩の 無水酢酸を加えて所定条件でアセチル化京行なったもの である。アセチル化後の試料は、グラスフィルターを用 いてポリマーをロ別し, メタノールで数回洗浄後, 水水 で2回,さらにェチルエーテルで 2 回洗浄して, 室温で 減圧乾燥した。ピリジンを用いたアセテル化においてみ られる以上の著しい安定性の向上が,この無触媒直接》 セチル化法で到達可能であり、ブロック共重合体にこの 方法を適用すれば，さらに安定性の向上を期待すること ができる。

\section{4. 考察}

アルカリ金属-芳香族炭化水素錯合体による重合では, 電子移動によりラジカルアニナンが形成され, ラジカル 端どうしが再結合してジアニオンを形成し，生長を続け てリビングポリマーが得られると，一般に考えられてい $ろ^{3)}$ 。この場合, ポリマー中には最初の触媒切片を含ま ない。

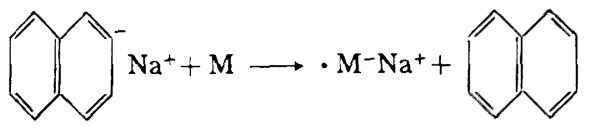

一方, nーブチルリチウムのような有機金属化合物を用 いると,

$$
\begin{aligned}
& (\mathrm{BuLi})_{n} \rightleftarrows \mathrm{BuLi}+(\mathrm{BuLi})_{n-1} \\
& \mathrm{BuLi}+\mathrm{M} \longrightarrow \mathrm{Bu} \cdot \mathrm{M}^{-} \mathrm{Li}^{+}
\end{aligned}
$$

のような開始反応が起こり，これにモノマーが付加して 生長を続け，一端に触媒切片をもったモノアニオンによ る生長機構となる。

このような状態で, 重合系にアセトアルデヒドを加え
ると, 前者の場合には, ジアニオン的に分子の両端で生 長が起こり, 後者の場合には, 一方向にのみアルデヒド が付加することになる。その結果, 前者では, 分子中に コモノマーブロックをもったブロック共重合体が得ら れ, 後者では, 分子の一端に翼種ブロックをもったポリ マーが得られるであろら。

$\mathrm{Na}^{+} \mathrm{M}^{-} \cdots \mathrm{M}^{-} \mathrm{Na}^{+}$<smiles>[M]C(C)C(C)[O+][NH+]C(C)O[NH3+]</smiles><smiles>[M]C(C)OCC(C)[O+][NH2+]C</smiles>

$\mathrm{Bu}-\mathrm{M} \cdot \mathrm{M}^{-} \mathrm{Li}^{+}$<smiles>[M]CC(C)OCC(C)OCC([M])C(C)O[Z17]</smiles>

重合采に不可避の微量不純物が存在すれば, アセトア ルデヒドの添加以前にジアニオンの一端が失活して, モ ノアニオンとして生長することも起こりらるし，また， リビングポリマーのラジカル端が溶媒からの水素引抜き などによって失活する場合にも，アルデヒドの重合では モノアニオンとして働くであろう。それゆえ, $n$-ブチル リチウムを触媒とする場合のブロック共重合体は, 分子 端にのみ異種ブロックをもつが，アルカリ金属一芳香族 炭化水素錯合体を触媒とする場合には, 実際上, 分子中 と分子端に異種ブロックを含むものの混合物であろらと 考えられる。

このほか,たとえば,ポリメタクリル酸メチルアニォ ンなどではモノマーへの連鎖移動の起こることが知られ ており5),7〜10)，また，スチレンのアニオン重合において 芳香族炭化水素溶媒への移動の起こることが認められて いるから ${ }^{11)}$ ，微量不純物による停止反応とともに，活性 を失ったホモポリマー生成の可能性もある。

アルカリ金属一芳香族炭化水素錯合体を用いる場合, 開 始反応が遅く，生長反応のはやい条件下では，触媒の残 存する可能性があり，また，nープチルリチウムを用いる ときにも，その会合性のために，上と同じ可能性がある。 この残存触媒によるアセトアルデヒドのホモ重合の生 
Table 3. Fractionation of acetaldehyde

\begin{tabular}{|c|c|c|c|c|c|c|c|}
\hline \multirow{3}{*}{ Exp. No. } & \multirow{3}{*}{ Comonomer } & \multirow{3}{*}{$D_{8.4} / D_{9.8}$} & \multirow{3}{*}{$m_{2}^{\mathrm{a})}$} & \multicolumn{4}{|c|}{ Acetone } \\
\hline & & & & \multicolumn{4}{|c|}{ Soluble } \\
\hline & & & & $(\%)$ & $\eta_{s p} / c$ & $D_{8.4} / D_{8.6}$ & $m_{2}^{\mathrm{a})}$ \\
\hline 1056 & \multirow{3}{*}{ Styrene } & 1.27 & 2.2 & 6.1 & 0.226 & - & - \\
\hline 1064 & & 1.37 & 2.1 & 12.0 & 0.205 & 0.98 & 21.0 \\
\hline 1065 & & 1.19 & 0.8 & 29.9 & 0.370 & 0.83 & 8.3 \\
\hline 1057 & \multirow{3}{*}{ MVP } & 1.33 & $<2$ & 14.6 & 0.251 & - & - \\
\hline 1058 & & 1.40 & - & 11.7 & 0.247 & - & - \\
\hline 1059 & & 0.92 & $<2$ & 34.4 & 0.427 & 0.94 & - \\
\hline 1060 & \multirow{3}{*}{$\begin{array}{l}\alpha \text {-Methyl-styrene } \\
\text { MMA }\end{array}$} & 1.45 & 0.6 & 9.2 & 0.207 & 1.02 & 6.0 \\
\hline 1062 & & 1.38 & 2.4 & 8.3 & 0.290 & - & - \\
\hline 1063 & & 0.89 & 0.5 & 38.0 & 0.466 & 0.82 & 1.5 \\
\hline 1067 & Isoprene & 1.29 & $4 \sim 8$ & 34.8 & 0.503 & 0.76 & - \\
\hline 1068 & \multirow{2}{*}{ Butadiene } & 1.05 & $<3$ & 45.8 & 0.458 & 0.74 & $S^{b)}$ \\
\hline 1069 & & 0.96 & $<3$ & 54.5 & 0.478 & - & $S^{b)}$ \\
\hline 1070 & Styrene & 1.10 & - & 53.7 & 0.846 & 1.08 & - \\
\hline 1071 & MVP & 1.11 & - & 57.2 & 1.128 & 0.95 & - \\
\hline 1073 & Styrene & 1.54 & - & - & - & - & - \\
\hline 1072 & MVP & 1.50 & - & - & - & - & - \\
\hline$L-151$ & Styrene & 1.35 & 5.5 & 26.1 & 0.255 & 0.95 & 26.5 \\
\hline$L-152$ & \multirow{2}{*}{ MMA } & 1.43 & 3.0 & 13.4 & 0.326 & - & - \\
\hline L-154 & & 1.39 & 0.7 & 5.9 & 0.147 & - & - \\
\hline L-153 & Butadiene & 1.59 & - & 20.3 & 0.222 & 1.04 & - \\
\hline L-155 & Isoprene & - & - & 10.7 & 0.202 & 0.71 & - \\
\hline L-157 & MVP & 0.99 & $S^{b)}$ & 32.0 & 0.530 & 0.90 & $S^{b)}$ \\
\hline L-159 & $\alpha$-Methyl-styrene & 1.07 & $S^{b)}$ & 24.2 & 0.248 & 1.03 & $S^{b)}$ \\
\hline
\end{tabular}

a) Composition of block copolymer ( $\mathrm{mol} \%$ of comonomer)

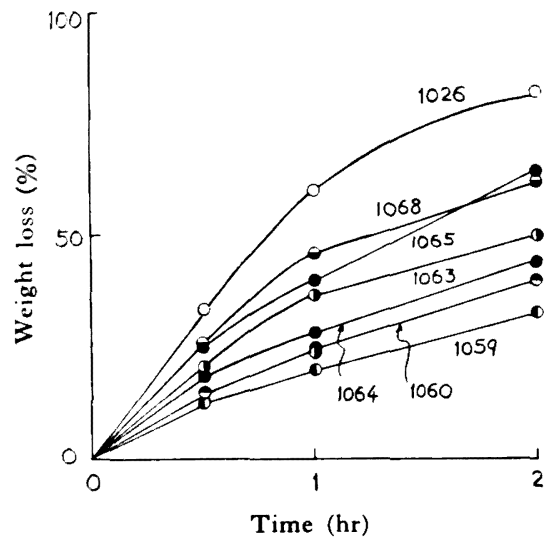

Comonomer: Styrene, D MVP, M MMA, $\odot \alpha$ Methyl styrene, Butadiene, $\bigcirc$ Without comonomer Catalyst : Sodium-naphthalene

Fig. 3. Thermal degradation of acetaldehyde block copolymers at $100^{\circ} \mathrm{C}$ under air.

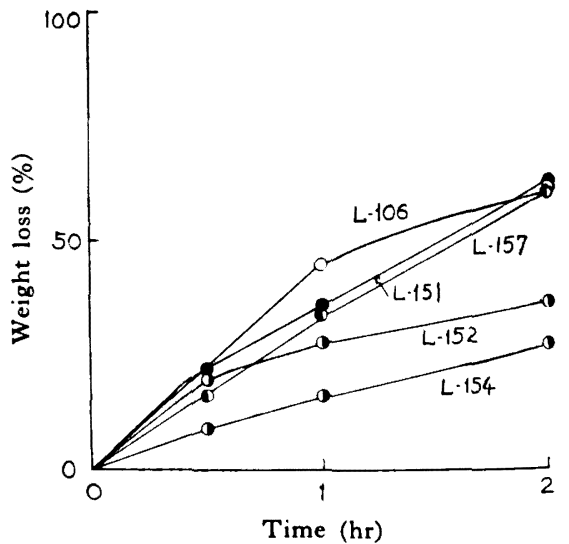

Comonomer: Styrene, D MVP, MMA, $\odot \alpha$ Methyl styrene, Butadiene, $\bigcirc$ Without comonomer Catalyst : $n$-Butyl lithium

Fig. 4. Thermal degradation of acetaldehyde block copolymers at $100^{\circ} \mathrm{C}$ under air. 
block copolymers $\left(30 \mathrm{C}^{\circ}\right)$.

\begin{tabular}{|c|c|c|c|c|c|c|c|c|c|}
\hline & & & \multicolumn{7}{|c|}{ Chloroform } \\
\hline \multicolumn{3}{|c|}{ Insoluble } & \multicolumn{4}{|c|}{ Soluble } & \multicolumn{3}{|c|}{ Insoluble } \\
\hline$(\%)$ & $D_{8.4} / D_{9.6}$ & $m_{2}^{\text {a) }}$ & $(\%)$ & $\eta_{s p} / c$ & $D_{8.4} / D_{9.6}$ & $m_{2}{ }^{a)}$ & $(\%)$ & $D_{8.4} / D_{9.6}$ & $m_{2}^{\mathrm{a})}$ \\
\hline 93.9 & - & - & 26.7 & 1.182 & - & - & 73.3 & 一 & - \\
\hline 88.0 & 1.54 & 0.7 & 54.6 & 0.816 & 1.19 & 5.3 & 45.4 & 1.73 & 0.7 \\
\hline 70.1 & 1.42 & 0.2 & 58.7 & 0.964 & 1.12 & 2.2 & 41.3 & 1.62 & 0.2 \\
\hline 85.4 & - & - & 67.0 & 0.874 & - & - & 33.0 & - & - \\
\hline 88.3 & - & - & 61.2 & 1.165 & - & - & 38.8 & - & - \\
\hline 65.6 & 1.28 & - & 63.7 & 1.295 & 1.15 & - & 36.3 & 1.44 & - \\
\hline 90.8 & 1.52 & 0.2 & 51.7 & 0.963 & 1.32 & 0.5 & 48.3 & 1.71 & 0.2 \\
\hline 91.7 & 1.49 & 0.6 & 33.6 & 1.284 & 1.40 & 6.0 & 66.4 & 1.57 & 0.4 \\
\hline 62.0 & 1.38 & 0.3 & 63.5 & 0.973 & 1.12 & 2.5 & 36.5 & 1.78 & 0.7 \\
\hline 65.2 & 1.49 & - & 54.5 & 1.257 & 1.00 & - & 45.5 & 1.83 & - \\
\hline 54.2 & 1.29 & $S^{b)}$ & 57.4 & 0.987 & 0.82 & $S^{b)}$ & 42.6 & 1.38 & $S^{b)}$ \\
\hline 45.5 & - & $S^{b)}$ & 71.6 & 1.047 & - & $S^{b)}$ & 28.4 & - & $S^{b)}$ \\
\hline 46.3 & 1.21 & - & 86.3 & 2.187 & 1.11 & - & 13.7 & - & - \\
\hline 42.8 & 1.13 & - & 84.7 & 2.065 & 1.08 & - & 15.3 & - & - \\
\hline- & - & - & - & - & - & - & - & - & - \\
\hline- & - & - & - & - & - & - & - & - & - \\
\hline 73.9 & 1.46 & 1.0 & 57.3 & 0.471 & 1.09 & 12.9 & 42.7 & 1.57 & 1.5 \\
\hline 86.6 & 1.62 & 1.6 & 32.4 & 2.157 & - & - & 67.6 & 1.63 & 1.2 \\
\hline 94.1 & 1.67 & 0.5 & 32.7 & 0.508 & - & - & 67.3 & 1.61 & $\mathrm{~S}^{\mathrm{b})}$ \\
\hline 79.7 & 1.61 & - & 63.7 & 0.541 & 1.21 & - & 36.3 & 1.64 & - \\
\hline 89.3 & 1.76 & - & 33.3 & 0.623 & 1.27 & - & 66.7 & 1.85 & - \\
\hline 68.0 & 1.21 & $S^{b)}$ & 79.8 & 2.148 & 0.92 & $S^{b)}$ & 20.2 & 1.33 & $S^{b)}$ \\
\hline 75.8 & 1.28 & $S^{b)}$ & 52.0 & 0.750 & - & $S^{b)}$ & 48.0 & 1.62 & $\mathrm{~S}^{\mathrm{b})}$ \\
\hline
\end{tabular}

b) Comonomer component was contained slightly.

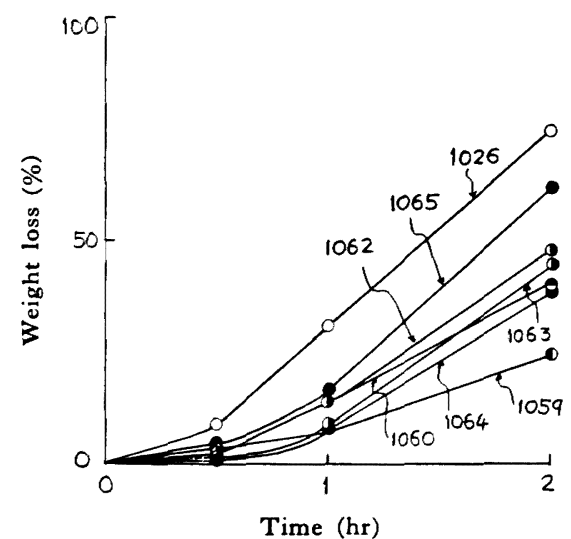

Comonomer :

Methl styrene, $\bigcirc$ Butadiene, $\bigcirc$ Without comonomer Catalyst: Sodium-naphthalene

Fig. 5. Thermal degradation of acetylated acetaldehyde block copolymers at $100^{\circ} \mathrm{C}$ under air.

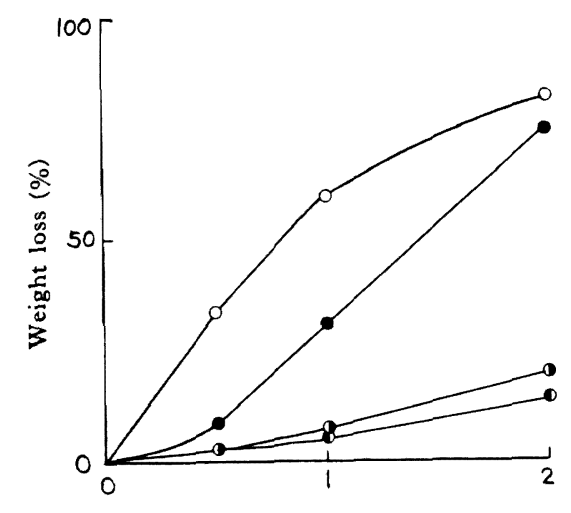

Time (hr)

$\mathrm{O}: 1026, \mathrm{O}: 1026$ (acetylated), D: A-1 acetylated), D: A-2 (acetylated)

Fig. 6. Thermal degradation of polyacetaldehyde at $100^{\circ} \mathrm{C}$ under air. 
a) Polymerization

Table 4. Preparation of samples A-1 and A-2.

\begin{tabular}{c|c|c|c|c|c}
\hline Exp. No. & $\begin{array}{c}\text { Catalyst } \\
\left(10^{-4} \mathrm{~mol}\right)\end{array}$ & $\begin{array}{c}\text { Acetaldehyde } \\
(\mathrm{m} l)\end{array}$ & $\begin{array}{c}\text { Solvent } \\
(\mathrm{m} l)\end{array}$ & $\begin{array}{c}\text { Polymerization } \\
\text { temp. }\left({ }^{\circ} \mathrm{C}\right)\end{array}$ & $\begin{array}{c}\text { Polymerization } \\
\text { time }(\mathrm{hr})\end{array}$ \\
\hline A-1 & Na-Naphthalene 4.7 & 10 & Toluene 20 & -100 & 3 \\
A-2 & Na-Naphthalene 4.7 & 10 & Toluene 20 & -100 & 3 \\
\hline
\end{tabular}

b) Acetylation

\begin{tabular}{c|c|c|c|c}
\hline \hline Exp. No. & Acetic-anhydride $(\mathrm{m} l)$ & Reaction temp. $\left({ }^{\circ} \mathrm{C}\right)$ & Reaction time $(\mathrm{hr})$ & Polymer yield $(\mathrm{g})$ \\
\hline A-1 & 10 & -78 & 15 & 2.12 \\
A-2 & 10 & Room temp. & 15 & 2.00 \\
\hline
\end{tabular}

起, あるいは，アニナン移動に基くアセトアルデヒドホ モポリマーの生成も考えられる。このように考えると， 本研究で得られたポリマーは, 明らかに種々のポリマー の混合物であるが，その中，重合溶媒に可溶な失活りビ ングポリマー, 非晶性ポリアセトアルデヒド, およびそ れらに近いポリマーは除かれていると思われる。

なお，本実験で得られたポリマーが，単なる混合物の みでないことは, Table 3 に示したごとく、リビングポ リマーから生ずるホモポリマーの共通溶媒であるク口ロ ホルムに不溶の部分の赤外吸収スペクトルに, これらの 成分の認められることから推定される。

ポリマーの安定性を支配する因子として，1）ポリマ 一の分子量，2）ポリマーの結晶性，3）ポリマーの組成 およびブロック効率，4）触媒残渣量，5）アセチル化を 施した場合の末端固定度などが考えられる。本研究で得 られた一連のブロック共重合体の安定性が，アセトアル デヒドホモポリマーのそれよりすぐれていることは, 古 川 $5^{(6)}$ の結果と一致するところであるが，各ブロック共 重合体間の安定性に差異のみられるのは, 上の諸因子が 交絡して現われているためと考えられる。

リビングポリマーにアセトアルデヒドを添加して第一 段のブロック形成後, さらに他のモノマーを添加すれば ポリアセトアルデヒドの両端固定が行なわれ，安定性の 向上が期待されるが，スチレンおよびアクリロニトリル を用いて検㶦したところでは否定的な結果に止まった。 このことは,ポリマー生長端のアルコラートアニオンが, 本研究の重合条件下において, これらのモノマーの重合 開始に必要な塩基性を欠くことと, 生長端が不均一相に あって，有刹に作用しないことなどによるものと考えら れる。

ピリジンー無水酢酸系によるアセチル化によって,ポリ マーの安定性の向上が認められるが, 真空下重合系に直 接無水酿酸を加えてアセチル化する方法は特に有効であ り，かなりの低温で反応を行なってもポリマーの安定性
は著しく向上する。

無水酢酸によるアセチル化の機構は, 次のように示さ れる。<smiles>CC([O-])OCCCCO</smiles><smiles>CC(=O)OCCCC(=O)OCC(=O)OCC(=O)[O-]</smiles>

このイオン機構に招いてポリマーアニオンの形成が律 速段階であるが，ピリジン一無水酢酸系ではポリマーが 結晶性のためピリジンに不溶であり, 反応系は不均一系 となってこの段階が有効に起こりにくいのに対して, 重 合采中には，すでに前報1),2)でふれたように潜伏状態で 残存するポリマーアニオンがあるため，比較的低温にお いても容易にア七チル化が起こるものと考えられる。

付 䟕：有益なご即論をいただいた京都大学工学部，古川泻 二教授, 発表の機会を与えられた会社当局, および実䮖敒協力 された徳氷昭夫君に感較します。なお，本研究はゴムおよび高 分子の研究発表会 (1963 年11月，名古星)に证てて報告した。

\section{文献}

1）滝田 博, 野呂 健：高化，21，445(1964)

2) 滝田 博, 野呂 健：高化, 21，452(1964)

3）たとえば，桑田敬治：「高分子の合成」（化学增刊 7), 73 (1961) 化学同人

4) R. K. Graham, D. L. Dunkelberger, W. E. Goode : J. Am. Chem. Soc., 82, 400(1960)

5) P. Claes, G. Smets : Makromol. Chem., 44/46, 212(1961)

6) H. Fujii, T. Fujii, T. Saegusa, J. Furukawa: Makromol. Chem., 63, 147 (1963) 
7) R. K. Graham, D. L. Dunkelberger, E. S. Cohen: J. Polymer Sci., 42, 501 (1960)

8) R. K. Graham, J. R. Panchak, M. T. Kampf : J. Polymer Sci., 44, 411 (1960)

9) M. Szwarc, A. Rembaum: J. Polymer Sci., 22, 189(1956)
10) M. Szwarc, M. Litt: J. Phys. Chem., 62, 568 (1958)

11) F. M. Brower, H. W. McCormick: J. Polymer Sci., A-1, 1749 (1963)

12）滝田 博, 野呂 健：高化，20，705(1963)

\title{
Anionic Polymerization of Aldehydes \\ III. Block Copolymerization of Acetaldehyde with Living Polymers
}

\author{
By Hiroshi Takida* and Ken Noro*
}

\begin{abstract}
Block copolymerization of acetaldehyde was attempted by addition of acetaldehyde into the solution of living polymers at low temperature. Living polymers of styrene, $\alpha$-methyl styrene, 2-methyl-5-vinylpyridine, methylmethacrylate, isoprene and butadiene were prepared with catalyst containing alkali metal such as alkali metal-aromatic complexes and $n$-butyl lithium.

Acetaldehyde could be polymerized by any of living polymers in toluene at $-100^{\circ} \mathrm{C}$ and polymer, which principal ingredient was crystalline polyacetaldehyde, was obtained. It was confirmed from the measurement of infrared spectrum of the polymer that block copolymer of both components has been prepared. These block copolymer were thermally more stable than homopoiymer of acetaldehyde.
\end{abstract}

\section{第 4 報 ナトリウムーナフタレン錯合体によるアルデド類の重合}

(1964 年3月 2日受理)

\author{
滝田 博**. 野呂 健**
}

\begin{abstract}
要旨 ナトリウムーナフタレン錯合体を触媒として, n-, iso-ブチルアルデヒド, およびクロラール の重合をー78 C Cで行ない，比較的高重合率でポリマーが得られることを認めた。nーブチルアルデヒドの重合 では，溶媒の極性が高くなると重合率低下の傾向がみられるが，iso-プチルアルデヒド，およびクロラールで は，エチルエーテルを溶媒に用いたときに重合率が最も高、。n-, 㧍よび iso-ブチルアルデヒドのポリマー は重合溶媒の種頛によらず結晶性である。スチレン, および 2-メチルー5-ビニルピリジンのリビングポリマー を用いてこれらのアルデヒドの重合を試み，ブロック共重合体の得られることを赤外吸收スペクトルから認め た。これらのポリマーは, いずれもクロロホルムに一部可溶であり,それらの安定性は, アルデヒドの種類に より異なる。
\end{abstract}

\section{1. 緒言}

塩基性触媒の存在下におけるアルデヒド類の反応は, 触媒, 溶媒の種類, アルデヒド濃度, および反応温度な どによって影響をらけるが,アルテヒド自体の種類の差 による影響も大きい。ホルムアルデヒドの重合に関して は, 別報1で詳細に研究を行なっているので, 本報では, アセトアルデヒドの立体規則性重合に有効なことを認め た Na-ナフタレン錯合体 ${ }^{2)}$ を触媒として, アセトアルデ
ヒドより側鎖の電子供給性の大きい $n$-, および iso-ブ チルアルデヒド, 電子吸引性の大きい 3 個の塩素原子を もつクロラールの重合について検討し，また，リビング ポリマーによるこれらのアルデヒドのブロック共重合体 の合成を二三試みた。

\section{2. 実験}

n-,および iso-ブチルアルテヒド： 市販品を精留 後, モレキュラーシープで脱水し，真空系に接続して高

* Central Research Laboratory, The Nippon Synthetic Chemical Industry Co., Ltd (156, Kamikema, Amagasaki, Hyogo)

** 日本合成化学工業株式会社中央研究所(兵庫県尼崎市上食満 156) 